\title{
Sustainability Atlas of Texas Ecoregions
}

\author{
Faye Anderson, Najla N. J. Al-Thani \\ Center for Advances in Water and Air Quality, Lamar University, Beaumont, USA \\ Email: andersonfaye7@gmail.com
}

Received 21 November 2015; accepted 20 December 2015; published 23 December 2015

Copyright @ 2015 by authors and Scientific Research Publishing Inc.

This work is licensed under the Creative Commons Attribution International License (CC BY). http://creativecommons.org/licenses/by/4.0/

(c) () D Den Access

\section{Abstract}

Since the introduction of the triple bottom line sustainability assessment accounting, a variety of approaches have been developed to quantify sustainability using the three axes of social, economic and environmental sustainability. The aim of this atlas is to assess the sustainability of Texas natural ecoregions: the Piney Woods, the Gulf Prairies and marshes, the Post Oak Savanah, the Blackland Prairies, the Cross Timbers, the South Texas Plains, the Edwards Plateau, the Rolling Plains, the High Plains and the Trans-Pecos, by identifying a set of indicators. These are unemployment, children in poverty, severity of housing problems, daily PM2.5 concentrations, population affected by drinking water violation, total water use, organic production, non-obesity and attainment of post-secondary education. Despite the limitations of inherent inaccuracies and temporal limitation, the assessment points to issues that negatively affect the environmental sustainability of Texas ecoregions. Continual assessment is recommended to optimize the atlas.

\section{Keywords}

Sustainability Assessment, Environmental Indicators, Economic Indicators, Social Indicators, Texas Ecoregions, Triple Bottom-Line, People Planet Profit

\section{Introduction}

"What we are doing to the forests of the world is but a mirror reflection of what we are doing to ourselves and to one another"-Mahatma Gandhi [1]. Sustainability definition progressed from measuring a corporate’s financial performance to a new three-dimensional framework of the three Ps: people, planet and profit, or triple bottom line (TBL) [2] [3]. According to EPA (2015), sustainability "is to create and maintain the conditions under which humans and nature can exist in productive harmony to support present and future generations” [4]. Because of its significance to the quality of life in the present and the future, normative and scientific aspects of sustainability have evolved in an attempt to qualify and quantify sustainability. These measurements have been shaping policy on the three main scopes: environmental, economic, and social [5]. However, for sustainability to be scientifically operationalized, it needs to be measured using a holistic system's interdisciplinary approach [6]. 
Triple Bottom Line (TBL) analysis has been the increasingly popular accounting management style because it assesses a system's success not by the financial bottom line only but by its social and environmental impacts. Although sustainability is a noble old concept, it brings more issues that producers, researchers, investors, consumers, and policy makers need to resolve in order to be able to implement it.

Texas is the second largest state after Alaska, covering 266,807 sq. miles, and having natural ecoregions: the Piney Woods, the Gulf Prairies and marshes, the Post Oak Savanah, the Blackland Prairies, the Cross Timbers, the South Texas Plains, the Edwards Plateau, the Rolling Plains, the High Plains and the Trans-Pecos [7]. Studying an ecoregion can provide insight on the sustainability baseline and potential for that ecoregion. But how can sustainability be quantified and measured for a Texas ecoregion? If it cannot be measured then how can they be qualified as being sustainable, or not? Also, how can two or more sustainable ecoregions be contrasted to each other in terms of sustainability? There has been some research that suggested developing indicators to measure the three bottom lines for ecoregions as indicators for sustainability [8], but it is still under development because of the complexity of studying the many variables that need to be accounted for.

"Defining an appropriate set of indicators for sustainable development is a difficult task" [9] because identifying too few indicators may ignore essential details whereas including too many indicators complicates data collection and analyses and result in non-feasible research. Hence, finding an optimal set of indicators is challenging [9] [10]. There are two categories for sustainability indicator identifying framework: system-based and content-based [11]. This research is based on holistic system-based framework. However, because the ecoregions represent the main trends given the available resources, this project presents a framework that is larger than the system, or more specifically it is at the sector level [12]. The systemic dimension plays an essential role when selecting and designing the indicators for sustainability assessment. In order to obtain an adequate system representation, three criteria should be met: parsimony, sufficiency and indicator interaction. In general, a system should be represented with as much simplicity as possible (parsimony) and as much complexity as necessary (sufficiency). This implies that, for obtaining an adequate system representation, the most relevant relations among the indicators have to be considered in the analysis [13]. The indicators and their relations have to represent the main structures, processes, and functions of the economic, ecological and social fields of the system studied and have to refer to the problems and targets to be tackled. In this context, the natural Texas ecoregion is the system of interest which is an economic, social and ecological entity that fulfills the previouslymentioned criteria.

A list of major sustainability projects in the United States are inventoried by Sustainable Measures (2010) [14]. Two standout as they are projects specific to Texas: Central Texas Sustainability Indicators Project and Austin Sustainable Community Initiative. Both are focused on the social aspect of sustainability. The former is designed to assess community indicators for five counties whereas the latter does that same for Austin area. Schader et al. (2014) [12] thoroughly assess thirty-five major sustainability assessment approaches pertinent to ecoregions all over the world. Two approaches stand out from the U.S. Fieldprint Calculator and IFSC. The first is focused on six crops: corn, cotton, rice, wheat, potatoes, and soybean; whereas the second is for Illinois farms. Neither of them takes into account the social nor the economic aspects of sustainability. For an indicator-based sustainability assessment to comprehensively and reliably reflect the significant features of the ecoregion, the research and results must be pursued in a society- and policy-conscious framework. Trans-disciplinary research perspectives are considered herewith as essential to accomplishing this task. Parameterizing and thus quantifying sustainable operations can be used to guide sustainable management. Furthermore, this study highlights the usually skipped important aspect of sustainability: people and the society. The purpose of this study is to develop a sustainability assessment tool for Texas ecoregions that can lead to informed decisions based on a holistic approach. Moreover, the proposed sustainability indicators can provide early warning to avoid social, economic, and environmental setbacks. Finally, they can drive new sustainability policies, innovations and measures.

\section{Methods}

The social aspect of any society is the most transformational because unlike environmental or economic aspects, it is the only aspect we have control over. The literature points to plethora of social indicators. Nevertheless, representative social indicators should reflect the "nature, meaning, pace, and course of social change" [15] in the US. As such the percentage of adults who are not obese (with body mass index BMI less than 30) and percentage of adults aged 25 to 44 with some post-secondary education, were selected as representative social indi- 
cators. As for environmental indicators, they should represent the quality of the environment in Texas ecoregions including air, water, and soil. In this study average daily particulate matter that are smaller than 2.5 micrometer (PM2.5) $\left(\mu \mathrm{g} / \mathrm{m}^{3}\right)$, percentage of population affected by water violation, total water Use (million gal/day) and organic production will be the four environmental indicators. The achievement of economic feasibility is vital to an ecoregion. Unemployment, children in poverty and severe housing problems were selected to represent the economic status. List of the nine proposed indicators are presented in Table 1. Pairwise associations were calculated. The selected indicators were summarized for the natural ecoregions for one year.

\section{Results}

Texas ecoregions are given in Figure 1. Pairwise associations between the indicators show strong positive correlation between the number of organic producers and total water use (Table 2). Non-obesity is negatively

Table 1. Proposed indicators, their scopes and descriptions.

\begin{tabular}{|c|c|c|}
\hline Scope & Indicator & Description \\
\hline Economic & Percent unemployed & $\begin{array}{l}\text { Percentage of population ages } 16+\text { unemployed and looking for } \\
\text { work [16] [17]. }\end{array}$ \\
\hline Economic & Percent children in poverty & Percentage of children (under age 18) living in poverty [18]. \\
\hline Economic & Percent severe housing problems & $\begin{array}{l}\text { Percentage of households with at least } 1 \text { of } 4 \text { housing } \\
\text { problems: overcrowding, high housing costs, or lack of } \\
\text { kitchen or plumbing facilities [19]. }\end{array}$ \\
\hline Environmental & Average daily PM2.5 $\left(\mu \mathrm{g} / \mathrm{m}^{3}\right)$ & $\begin{array}{l}\text { Average daily amount of fine particulate matter in } \\
\text { micrograms per cubic meter [20]. }\end{array}$ \\
\hline Environmental & Percent in drinking water violation & $\begin{array}{l}\text { Population affected by a water violation/Total } \\
\text { population with public water [21]. }\end{array}$ \\
\hline Environmental & Water use (million gal/day) & Water use (fresh and saline), in million gal/day [22]. \\
\hline Environmental & Organic production & Number of organic producers [23]. \\
\hline Social & Percent non-obese & Percentage of adults that report BMI $<30$ [24]. \\
\hline Social & Percent some college & $\begin{array}{l}\text { Percentage of adults age } 25 \text { - } 44 \text { with some } \\
\text { post-secondary education [25]. }\end{array}$ \\
\hline
\end{tabular}

Table 2. Pairwise correlations between the proposed indicators.

\begin{tabular}{|c|c|c|c|c|c|c|c|c|c|}
\hline & $\begin{array}{l}\text { Water use } \\
\text { (million } \\
\text { gallon/day) }\end{array}$ & $\begin{array}{l}\text { Number of } \\
\text { organic } \\
\text { producers }\end{array}$ & $\begin{array}{l}\% \text { No } \\
\text { obese }\end{array}$ & $\begin{array}{l}\text { \% Some } \\
\text { college }\end{array}$ & $\begin{array}{c}\% \\
\text { Unemployed }\end{array}$ & $\begin{array}{c}\% \\
\text { Children in } \\
\text { poverty }\end{array}$ & $\begin{array}{c}\text { Average } \\
\text { daily PM25 }\end{array}$ & $\begin{array}{l}\text { \% In drinking } \\
\text { water viol }\end{array}$ & $\begin{array}{c}\text { \% Severe } \\
\text { housing } \\
\text { problems }\end{array}$ \\
\hline $\begin{array}{l}\text { Water use (million } \\
\text { gallon/day) }\end{array}$ & 1.00 & & & & & & & & \\
\hline $\begin{array}{l}\text { Number of organic } \\
\text { producers }\end{array}$ & 0.81 & 1.00 & & & & & & & \\
\hline$\%$ Obese & 0.55 & 0.28 & 1.00 & & & & & & \\
\hline$\%$ Some college & 0.17 & 0.24 & -0.05 & 1.00 & & & & & \\
\hline \% Unemployed & 0.40 & 0.19 & -0.46 & -0.50 & 1.00 & & & & \\
\hline $\begin{array}{l}\text { \% Children in } \\
\text { poverty }\end{array}$ & -0.13 & -0.26 & -0.20 & -0.73 & 0.75 & 1.00 & & & \\
\hline $\begin{array}{l}\text { Average daily } \\
\text { PM25 }\end{array}$ & -0.27 & -0.38 & 0.48 & -0.32 & -0.32 & -0.28 & 1.00 & & \\
\hline $\begin{array}{l}\text { \% In drinking } \\
\text { water viol }\end{array}$ & -0.41 & -0.20 & 0.06 & 0.26 & -0.72 & -0.33 & -0.03 & 1.00 & \\
\hline $\begin{array}{c}\text { \% Severe housing } \\
\text { problems }\end{array}$ & 0.25 & 0.34 & -0.29 & -0.21 & 0.75 & 0.61 & -0.68 & -0.59 & 1.00 \\
\hline
\end{tabular}




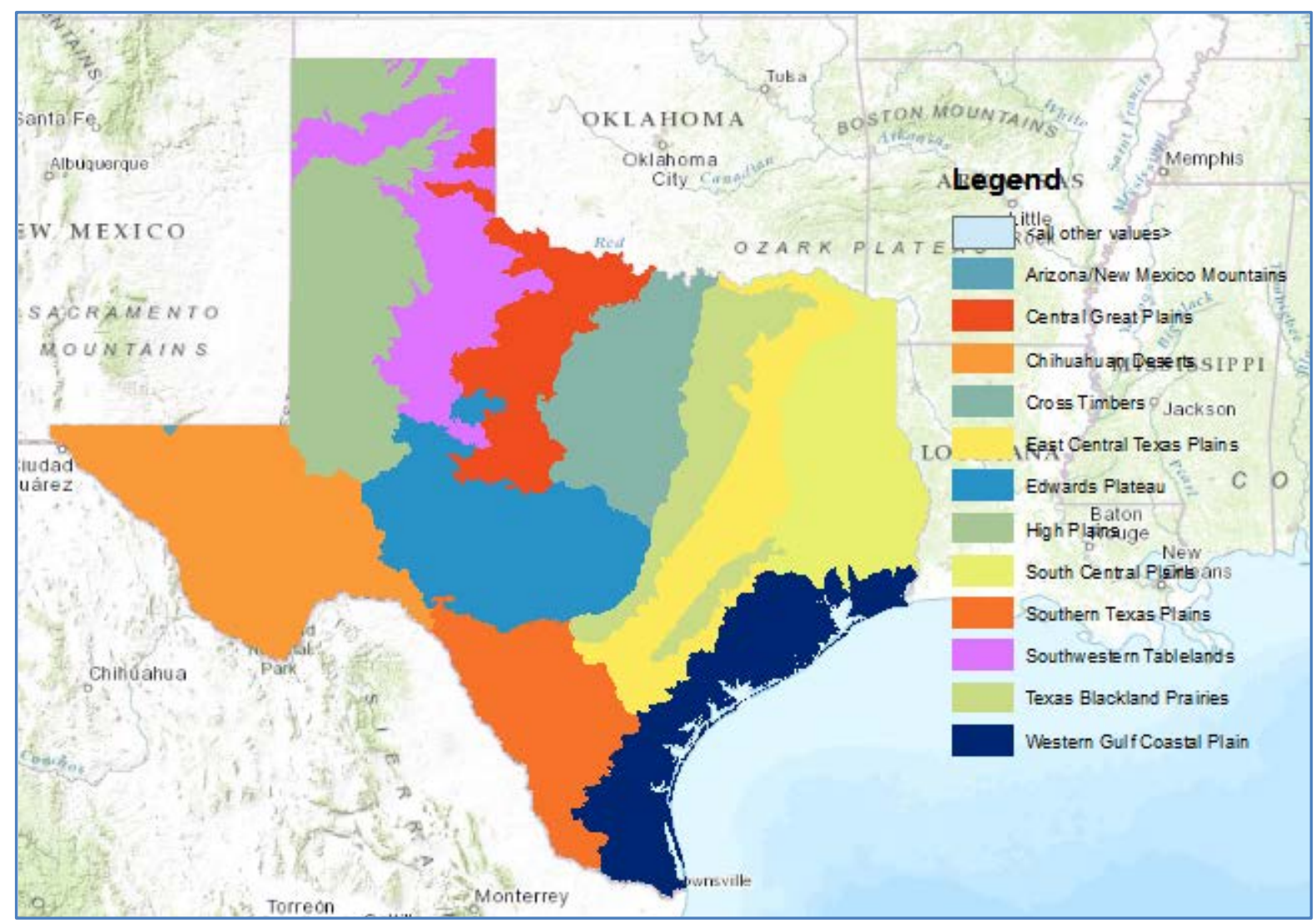

Figure 1. Texas ecoregions [26].

correlated with unemployment and positively correlated with daily PM2.5 concentrations. Moreover, unemployment is strongly positively associated with percentage of children in poverty and severe housing problems. However, it is strongly negatively associated with percentage of population in areas with drinking water violation. Severe housing problems is strongly positively associated with percentage of children in poverty and negatively associated with daily PM2.5 concentrations. Severe housing problems are negatively associated with percentage of population affected by drinking water violation. Percentages of harvested acres in each ecoregion are given in Figure 2. Southwestern Tablelands are mostly agricultural whereas only two percent of Chihuahuan Deserts are. Economic sustainability is the average of the three economic indicators of unemployment, children in poverty and severity of housing problems (Figure 3).

\section{Discussion}

Of the three bottom lines, environmental sustainability was the lowest compared to the social and economic scopes, ranging between 27\% for Edwards Plateau and 34\% for the High Plains (Figure 3). This means that Texas ecoregions environmental sustainability needs attention from policy makers in order to address the issues that negatively affect its degree of sustainability. The highest degrees of sustainability were observed in the economic indicators which averaged from $80 \%$ for Southern Texas Plains to $89 \%$ for the Central Great Plains (Figure 4). Social sustainability ranged from $57 \%$ for the Chihuahuan Deserts to $63 \%$ for Texas Blackland Prairies (Figure 5). Overall sustainability ranged from $55 \%$ for Southern Texas Plains to $60 \%$ for Texas Blackland Prairies (Figure 6).

Despite the simplicity of this assessment method, data accuracy might be an issue especially that most of the data collected has inherent accuracies and some being "best estimates" as opposed to field measurements. Spatiality is built in sustainability assessment. Hence, relevance and applicability to other locations depend on similarities to Texas ecoregions. TBL based sustainability assessment is flexible and easy to customize [8]. Achieving sustainability is like chasing a moving target because of the inherent subjectivity in selecting the indicators 


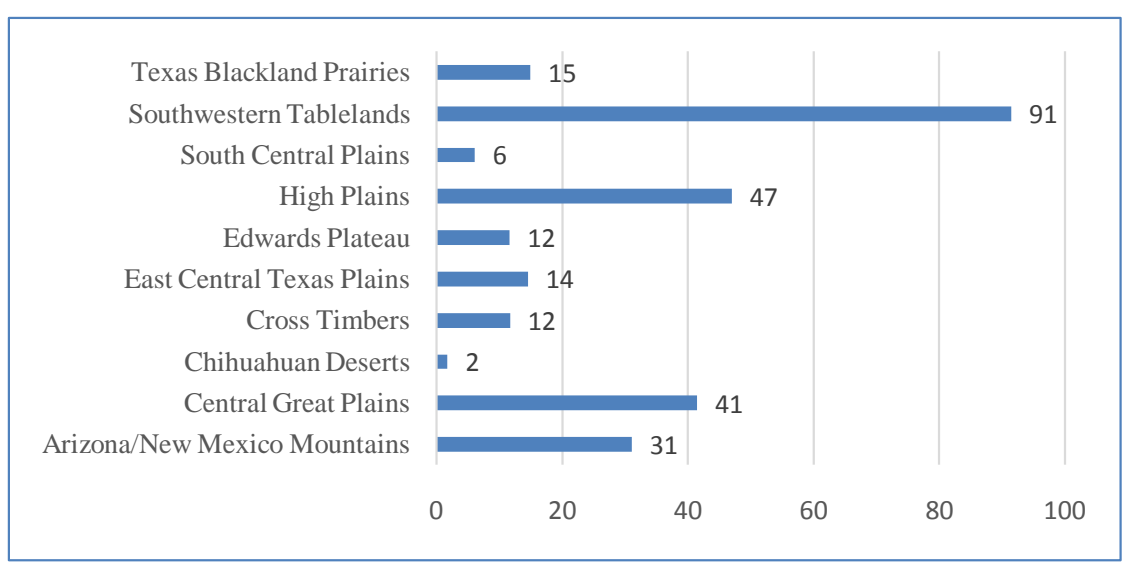

Figure 2. Percentage of harvested acres in Texas ecoregions.

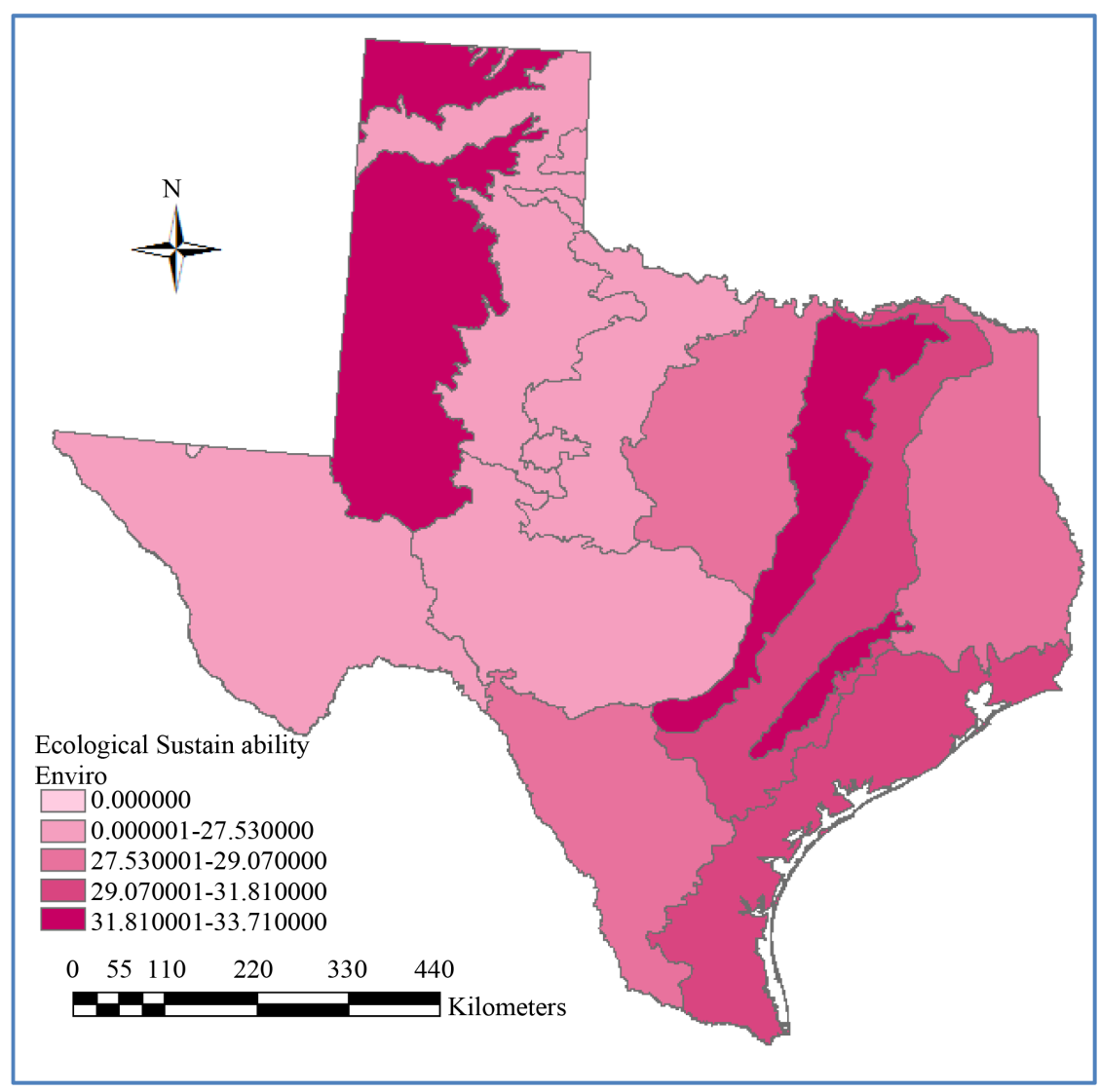

Figure 3. Ecological sustainability of Texas ecoregions.

due to reasons related to ease of access or ease of calculation. Moreover, the investigated indicators were for one year. That is, the results' applicability is limited and this calls for continuous assessment in order to ensure temporal suitability, accuracy of data and selection of the most representative indicators.

\section{Conclusion}

This research is an example of quantifying sustainability for Texas ecoregions using the three bottom lines of people, planet and profit. The assessment quantifies the social, economic and environmental aspects using nine indicators: unemployment, children in poverty, severity of housing problems, daily PM2.5 concentrations, 


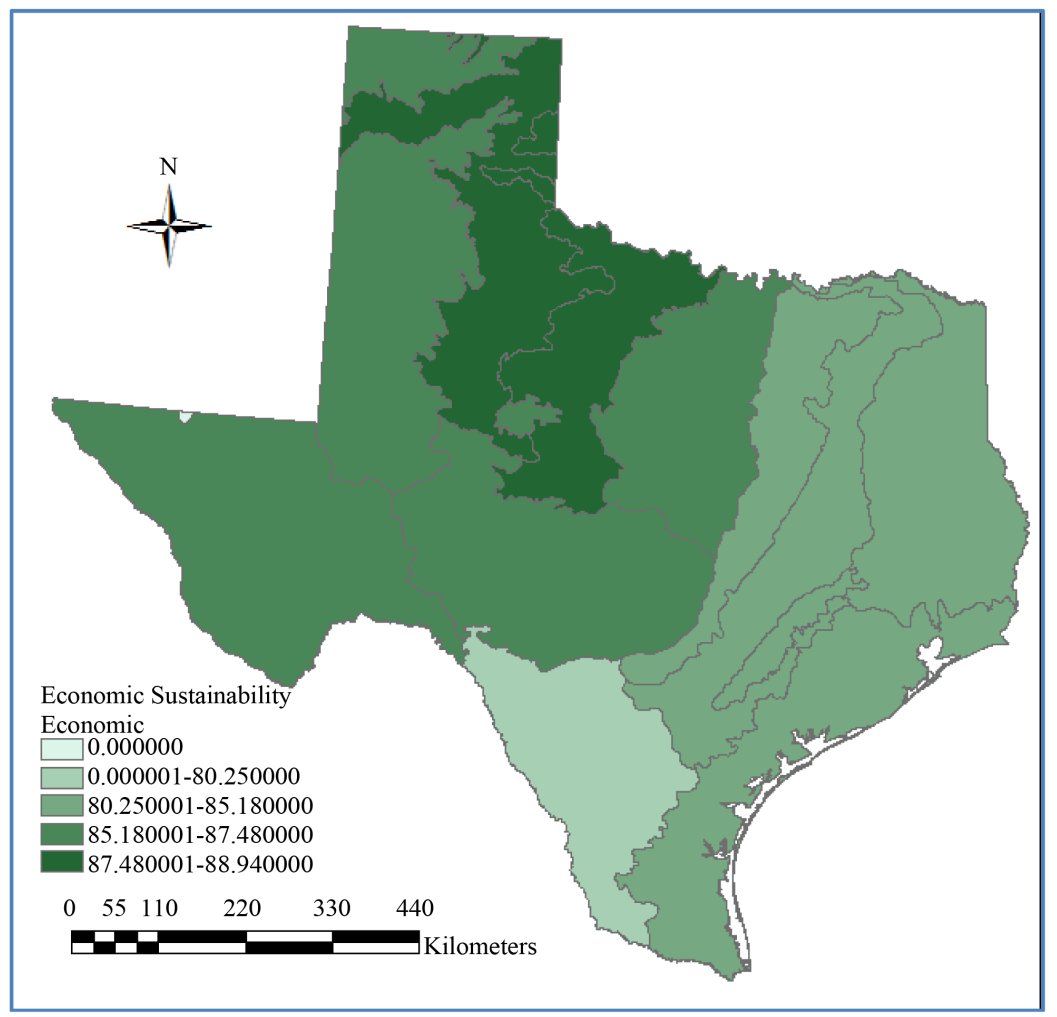

Figure 4. Economic sustainability of Texas ecoregions.

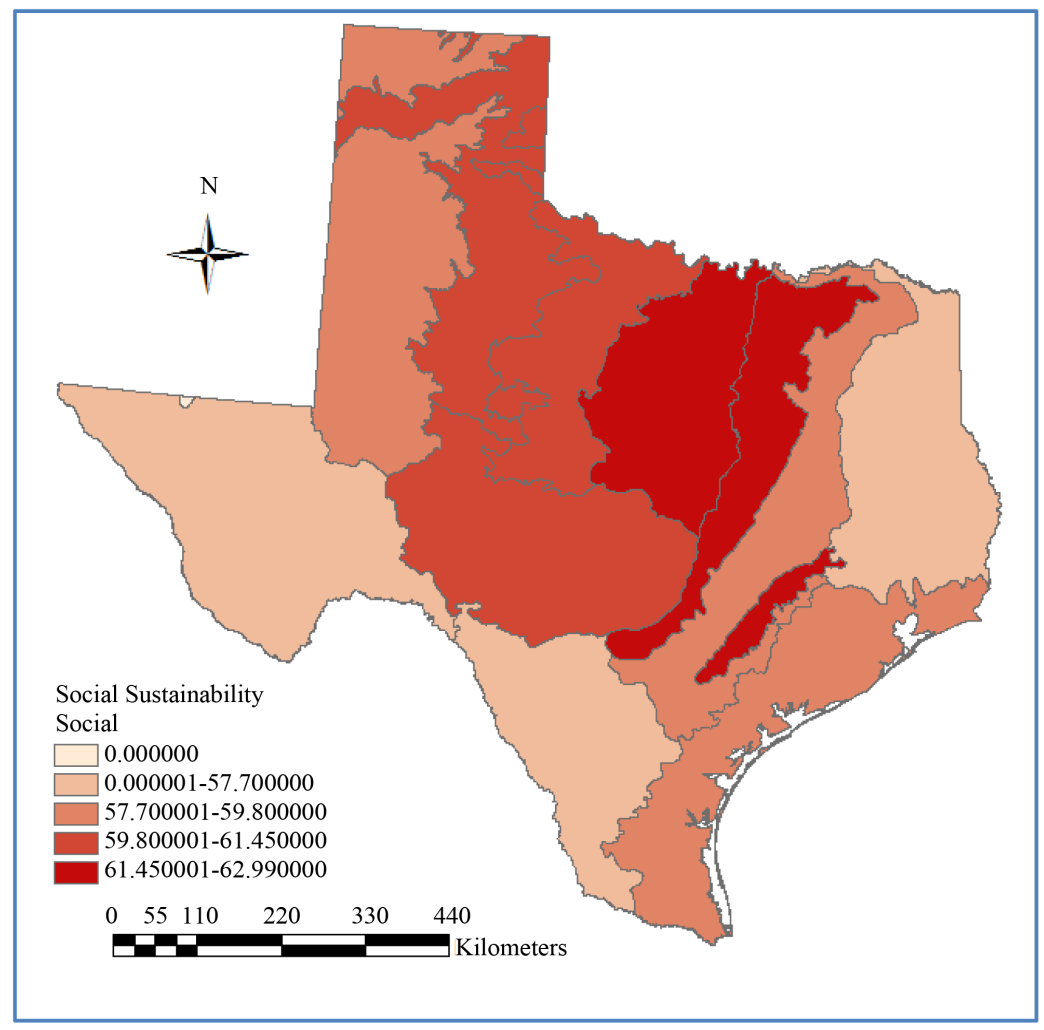

Figure 5. Social sustainability of Texas ecoregions. 


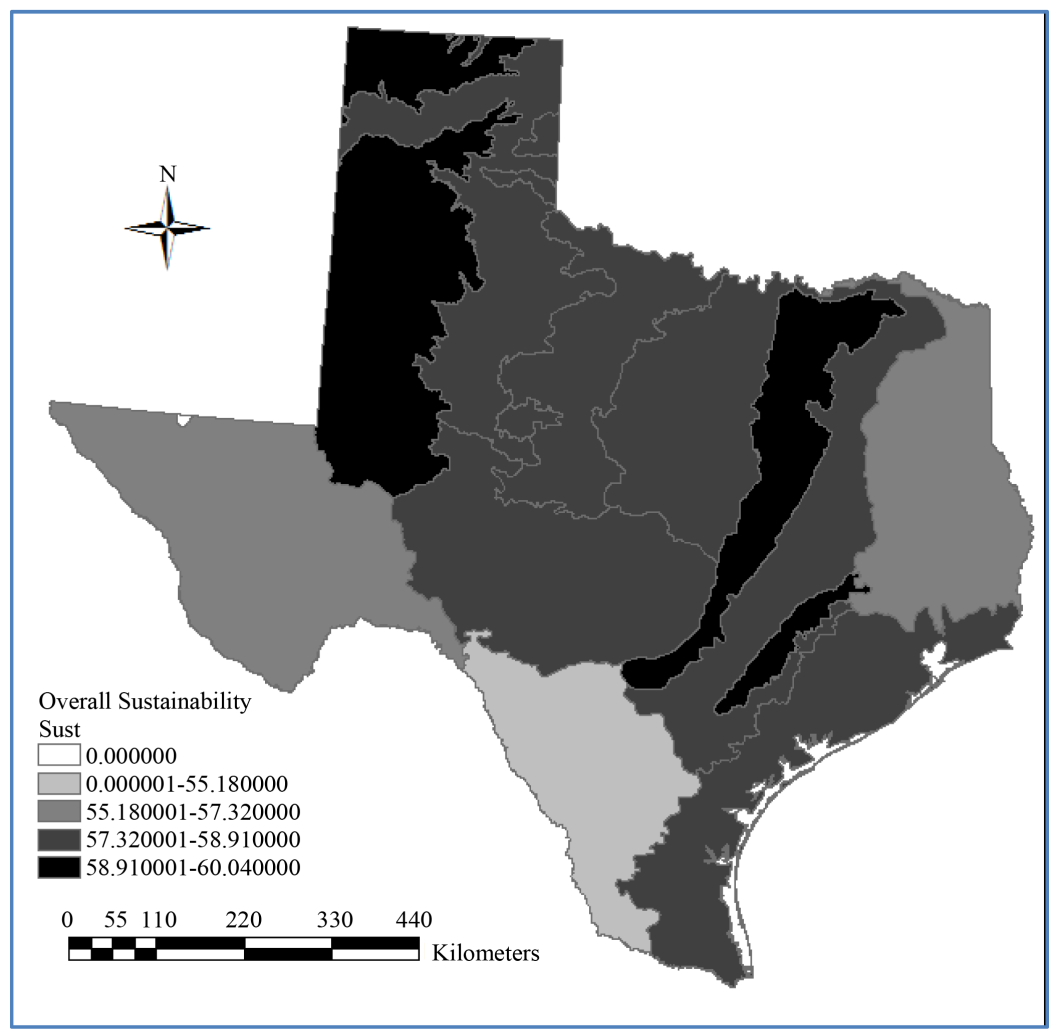

Figure 6. Overall sustainability of Texas ecoregions.

population affected by drinking water violation, total water use, organic production, non-obesity and attainment of post-secondary education. The results point to certain needs in the different ecoregions especially on the environmental aspect. Further analyses are required to test and validate the atlas in terms of time, data accuracy and identification of the best set of representative indicators.

\section{References}

[1] Scott, D.B., Frail-Gauthier, J. and Mudie, P.J. (2014) Coastal Wetlands of the World: Geology, Ecology, Distribution and Applications. Cambridge University Press, Cambridge. http://dx.doi.org/10.1017/cbo9781107296916

[2] Elkington, J. (1994) Towards the Sustainable Corporation: Win-Win-Win Business Strategies for Sustainable Development. California Management Review, 36, 90-100. http://dx.doi.org/10.2307/41165746

[3] Anderson, F. (2015) The Development of Rural Sustainability Using Participatory Action Research: A Case Study from Guatemala. Journal of Human Resource and Sustainability Studies, 3, 28-33. http://dx.doi.org/10.4236/jhrss.2015.31004

[4] EPA (2015) Learn About Sustainability. http://www2.epa.gov/sustainability/learn-about-sustainability

[5] WCED (World Commission on Environment and Development) (1987) Our Common Future. Report of the World Commission on Environment and Development. WCED, Switzerland.

[6] Lantermann, E.-D. (1996) Nachhaltigkeitals Leitlinieinterdisziplinzrer Umweltforschung. Paper Presented at a Seminar on "Nachhaltige Ressourcennutzung," Kassel University, Witzenhausen, 11 July 1996.

[7] TPWD (2015) Texas Ecoregions. https://tpwd.texas.gov/education/hunter-education/online-course/wildlife-conservation/texas-ecoregions

[8] Slaper, T.F. and Hall, T.J. (2011) The Triple Bottom Line: What Is It and How Does It Work? http://www.ibrc.indiana.edu/ibr/2011/spring/article2.html

[9] Bossel, H. (2001) Assessing Viability and Sustainability: A Systems-Based Approach for Deriving Comprehensive Indicator Sets. Conservation Ecology, 5, 12.

[10] Mitchell, G., May, A. and McDonald, A. (1995) PICABUE: A Methodological Framework for the Development of In- 
dicators of Sustainable Development. International Journal of Sustainable Development and World Ecology, 2, 104123. http://dx.doi.org/10.1080/13504509509469893

[11] von Wirén-Lehr, S. (2001) Sustainability in Agriculture-An Evaluation of Principal Goal-Oriented Concepts to Close the Gap between Theory and Practice. Agriculture, Ecosystems \& Environment, 84, 115-129. http://dx.doi.org/10.1016/S0167-8809(00)00197-3

[12] Schader, C., Grenz, J., Meier, M.S. and Stolze, M. (2014) Scope and Precision of Sustainability Assessment Approaches to Food Systems. Ecology and Society, 19, 42. http://dx.doi.org/10.5751/ES-06866-190342

[13] Wiek, A. and Binder, C. (2005) Solution Spaces for Decision-Making-A Sustainability Assessment Tool for CityRegions. Environmental Impact Assessment Review, 25, 589-608. http://dx.doi.org/10.1016/j.eiar.2004.09.009

[14] Sustainable Measures (2010) Sustainability Projects for United States. http://www.sustainablemeasures.com/projects/Sus/Sustainability/5

[15] Andrews, F.M. and Withey, S.B. (2012) Social Indicators of Well-Being: Americans’ Perceptions of Life Quality. Springer, New York.

[16] US Census (2015) 2013 All Ages in Poverty. http://www.census.gov/did/www/saipe/data/interactive/saipe.html?s_appName=saipe\&map_yearSelector=2013\&map geoSelector=aa_c

[17] Bureau of Labor Statistics (BLS) (2015) Local Area Unemployment Statistics. http://www.bls.gov/lau/

[18] US Census (2015) Poverty Data. https://www.census.gov/hhes/www/poverty/data/

[19] County Health Ranking \& Roadmaps (CHRR) (2015) How Healthy Is Your Community? http://www.countyhealthrankings.org/

[20] EPA (2015) AirData. http://www3.epa.gov/airdata/ad_basic.html

[21] EPA (2015) EnviroFacts. http://www3.epa.gov/enviro/facts/sdwis/search.html

[22] USGS (2015) Total Water Use. http://water.usgs.gov/watuse/wuto.html

[23] USDA (2015) Organic Production. http://www.ers.usda.gov/data-products/organic-production.aspx

[24] Centers for Disease Control and Prevention (CDC) (2015) Data and Statistics. http://www.cdc.gov/diabetes/data/index.html

[25] US Census (2015) Educational Attainment. http://www.census.gov/hhes/socdemo/education/

[26] EPA (2015) Ecoregions of Texas. http://archive.epa.gov/wed/ecoregions/web/html/tx_eco.html 